\title{
Penatalaksanaan infeksi herpes simpleks oral rekuren Management of recurrent oral herpes simplex infection
}

\author{
${ }^{1}$ Erni Marlina, ${ }^{2}$ Bagus Soebadi \\ ${ }^{1}$ PPDGS Ilmu Penyakit Mulut Fakultas Kedokteran Gigi Universitas Airlangga \\ ${ }^{2}$ Departemen Ilmu Penyakit Mulut Fakultas Kedokteran Gigi Universitas Airlangga \\ Indonesia
}

\begin{abstract}
Recurrent oral herpes simplex infection was the secondary or recurrent form of primary herpes simpex infection. In human, herpes simplex virus was latent or dormant and could reactivate. Recurrency due to virus reactivation induced by emotional stress, high fever, ultraviolet exposed, oral tissue or neuron tissue trauma, immunosuppresion condition, and hormonal disturbance. The aim of this paper was to report and discuss management of recurrent oral herpes simplex infection which complicated in the diagnosis due to manifestation of both herpes labialis and intraoral lesion form resembling herpes simplex infection. Patient was a 22 years- old woman, came to Installaton of Dental, dr. Soetomo Hospital with chief complaint pain were soreness caused by ulcer on the tongue accompanied by tingling near the upper labial mucosal. Patient was prescribed with acyclovir as causative therapy, mouthwash contain extract of aloe vera, multivitamins and immunomodulator as supportive therapy. Patient healed 4 days after the first visit. It was concluded that this case was diagnosed clinically as recurrent oral herpes simplex infections. Causative therapy with acyclovir administration showed excellent response, as well as supportive therapy immunomodulator that supported improvement of the immune system so that the frequency of recurrence can be reduced.
\end{abstract}

Key words: herpes labialis, recurrent intraoral herpes, herpes simplex virus infection, acyclovir

\begin{abstract}
ABSTRAK
Infeksi herpes simpleks oral rekuren merupakan bentuk sekunder atau rekuren dari infeksi herpes simpleks primer. Pada manusia virus herpes simpleks bersifat laten atau dormant dan dapat mengalami reaktivasi. Rekurensi akibat reaktivasi virus diinduksi oleh stres emosi, demam tinggi, paparan sinar ultraviolet, trauma jaringan mukosa rongga mulut atau jaringan saraf, kondisi imunosupresi, dan gangguan hormon. Laporan kasus ini bertujuan untuk melaporkan dan membahas tatalaksana dari infeksi herpes simpleks oral rekuren dengan penyulit penegakan diagnosis karena manifestasi klinisnya berupa herpes labialis dan herpes simpleks intraoral pada seorang perempuan yang berusia 22 tahun, yang datang ke Instalasi Gigi Mulut RSUD dr. Soetomo dengan keluhan rasa nyeri, panas, akibat sariawan di lidah disertai rasa menebal pada bibir atas. Pasien diterapi dengan acyclovir sebagai terapi kausatif, obat kumur yang mengandung ekstrak aloe vera, multivitamin dan imunomodulator sebagai terapi simtomatik dan suportif. Pasien sembuh 4 hari setelah kunjungan pertama. Disimpulkan bahwa kasus ini didiagnosis klinis sebagai infeksi herpes simpleks oral rekuren. Terapi kausatif dengan pemberian acyclovir menunjukkan respon yang sangat baik, demikian juga dengan terapi suportif imunomodulator yang mendukung perbaikan sistem imun sehingga frekuensi rekurensi dapat dikurangi.
\end{abstract}

Kata kunci: herpes labialis, herpes intraoral rekuren, infeksi virus herpes simpleks, acyclovir

Koresponden: Erni Marlina, Bagian Oral Medicine Fakultas Kedokteran Gigi Universitas Hasanuddin, Jl. Kandea No.5, Makassar, Indonesia.E-mail: e.marlina@yahoo.co.id

\section{PENDAHULUAN}

Infeksi herpes simpleks oral rekuren merupakan bentuk sekunder atau rekuren dari infeksi herpes simpleks primer. Herpes simpleks adalah penyakit yang disebabkan oleh virus herpes simpleks (VHS) yang merupakan virus DNA.Virus ini terdiri dari dua kelompok utama yang dapat menginfeksi manusia, yaitu VHS tipe 1 dan tipe $2 .{ }^{1}$ Pada manusia, VHS bersifat laten atau dormant dan dapat mengalami reaktivasi.Kemungkinan terjadi rekurensilesi sebesar 30-40\%. Lesi infeksi rekuren bermanifestasi dalam dua bentuk,yaitu lesi yang sering terjadi pada daerah di dekat bibir yang dikenal dengan nama herpes labialis atau cold sore, dan lesi pada rongga mulut yang disebut infeksi herpes simpleks intraoral rekuren. ${ }^{2-4}$
Lesi rekuren di daerah sekitar wajah lebih sering dijumpai dibanding lesi intraoral.

Di Amerika Serikat, prevalensi herpes labialis diperkirakan 20-40\%,dengan hampir 100 juta episod kejadian pertahun. ${ }^{3}$ Rekurensi akibat reaktivasi virus ini diinduksi oleh stres emosi, demam tinggi,paparan sinar ultraviolet,trauma jaringan oral atau jaringan saraf, ${ }^{3}$ kondisi imunosupresi,dan gangguan hormon. ${ }^{2}$

Dalam artikel ini akan dilaporkan dan dibahas kasus infeksi herpes simpleks oral rekuren yang bermanifestasi sebagai herpes labialis yang diterapi dengan agen antivirus dan imunomodulator.

\section{KASUS}

Seorang pasien perempuan yang berusia 22 tahun 

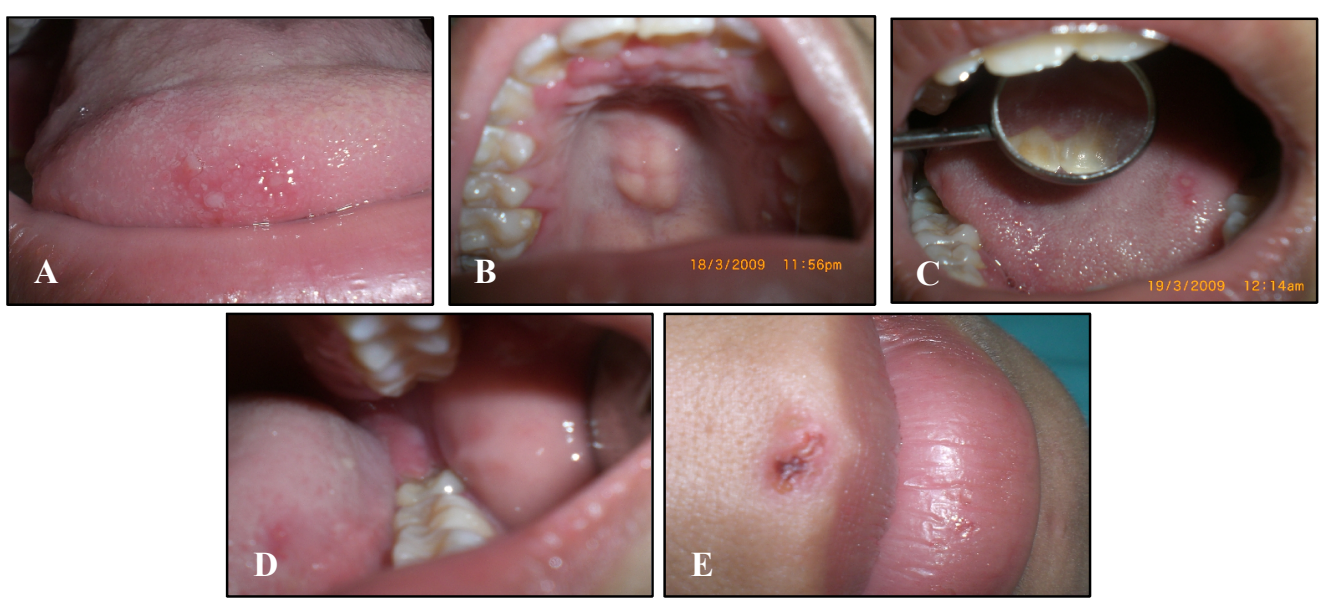

Gambar 1 Kunjungan I, tampak lesi pada $\mathbf{A}$ anterior lidah, B palatum regio molar dan garis tengah palatal di daerah rugae palatina, $\mathbf{C}$ dorsum lidah, $\mathbf{D}$ peradangan pada gingiva molar ketiga, E vesikula di daerah perioral.

yang bekerja sebagai apoteker di RSUD. dr. Soetomo, datang ke Instalasi Gigi Mulut RSUD dr. Soetomo dengan keluhan rasa nyeri, panas akibat sariawan di lidah disertai rasa menebal pada bibir atas yang muncul sekitar 1 minggu yang lalu. Pada saat sebelum munculnya sariawan pasien merasa meriang, demam, seperti akan timbul influensa. Pasien minum obat, diantaranya tablet kunyah yang mengandung fradiomisina $2,5 \mathrm{mg}$ kombinasi yang dikombinasi dengan gramisidona-S $1 \mathrm{mg} 3 \times 1$ selama 4 hari, tetapi tidak sembuh. Pasien tidak ingat apakah sariawan tumbuh bersamaan rasa nyeri di tenggorokan, tapi kemungkinan setelah adanya rasa nyeri di tenggorokan. Sebelumnya pasien tidak pernah sariawan. Pasien tidak tahu mengenai keberadaan lesi di atas bibirnya, dan tidak ingat sejak kapan lesi tersebut muncul. Pasien kemudian periksa ke ahli penyakitdalamdandiberi klindamisin serta natrium diklofenak,juga pemeriksaan darah lengkap; namun hasilnya normal, hanya $\mathrm{Hb}$ yang menunjukkan nilai $10 \mathrm{mg} / \mathrm{dl}$ dari nilai normal 11$13 \mathrm{mg} / \mathrm{dl}$. Pasien kemudian dirujuk ke Instalasi Gigi Mulut RSUD dr. Soetomo.

Menurut ingatannya, pasien pernah menderita penyakit yang menurut dokter yang memeriksa adalah penyakit herpes yang tandanya berupa beberapa bercak merah di bagian punggung, pada waktu kecil. Tidak ada riwayat alergi, dan pasien sedang dalam kondisi lelah setelah mengikuti prajabatan selama 3 minggu.

Pada pemeriksaan ekstraoral, dijumpai adanya lesi berupa krusta kering, merah dengan vesikula di atas bibir dengan diameter $2 \mathrm{~mm}$. Kelenjar limfe kiri dan kanan teraba lunak dan nyeri.

Pada pemeriksaan intraoral nampak 3 lesi ulser diameter 0,5 dan $1,5 \mathrm{~mm}$ di daerah $1 / 3$ anterior lidah, 1 lesi ulser di daerah rugae palatina tertutup pseudomembran warna putih kekuningan dikelilingi daerah eritema bentuk bulat. Eritema dengan diameter $2 \mathrm{~mm}$ juga dijumpai di daerah sekitar faring dan dijumpai adanya perikoronitis di daerah molar ketiga kiri dan kanan rahang bawah serta peradangan palatogingiva di daerah insisivus rahang atas (gambar 1).

\section{PENATALAKSANAAN}

Berdasar anamnesis dan gambaran klinis, diagnosis kasus ini adalah infeksi herpes simpleks oral rekuren dengan diagnosis banding stomatitis aftosa rekuren (SAR). Prinsip perawatan yang akan dijalankan adalah pemberian terapi kausatif, simtomatik, dan suportif.

Pasien diterapi dengan acyclovir $200 \mathrm{mg} 5 \times 1$ untuk 5 hari sebagai terapi kausatif, ekstrak aloe vera kumur untuk pemakaian $3 \times 1$ untuk 5 hari, Echinacea $250 \mathrm{mg}$ tablet $1 \times 1$ untuk 10 hari, dan multivitamin yang mengandung vitamin $\mathrm{E}$, vitamin $\mathrm{C}$, asam folat, vitamin $\mathrm{B} 1$, vitamin $\mathrm{B} 2$, niasin, vitamin B6, vitamin B12, asam pantotenant, dan $\mathrm{Zn}$, tablet $1 \mathrm{x} 1$ untuk 10 hari yang merupakan terapi simtomatif dan suportif.

Pasien diinstruksikan untuk memakai pasta gigi yang mengandung aloe vera untuk membantu mengurangi inflamasi, menghindari faktor yang mungkin sebagai pencetus, misalnya paparan sinar matahari yang berlebihan, atau stres fisik yang berlebihan, serta sedapat mungkin mengisolasi diri untuk menghindarkan penularan virus ke orang lain karena pasien sedang dalam tahap infeksius. Untuk membantu penyembuhan, pasien diminta untuk beristirahat. Selanjutnya, pasien diminta kontrol 5 hari kemudian. 


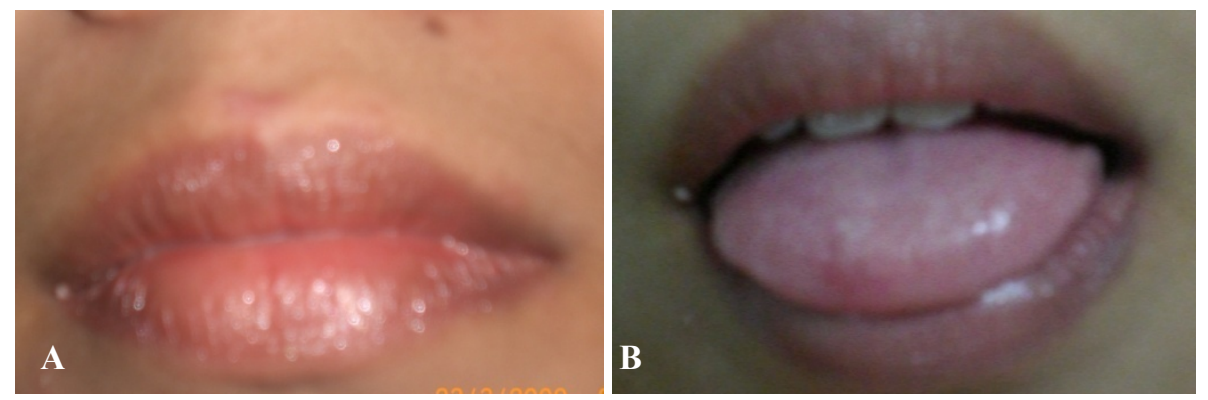

Gambar 2 Kontrol I; A lesi labial telah sembuh, B lesi di lidah telah sembuh.

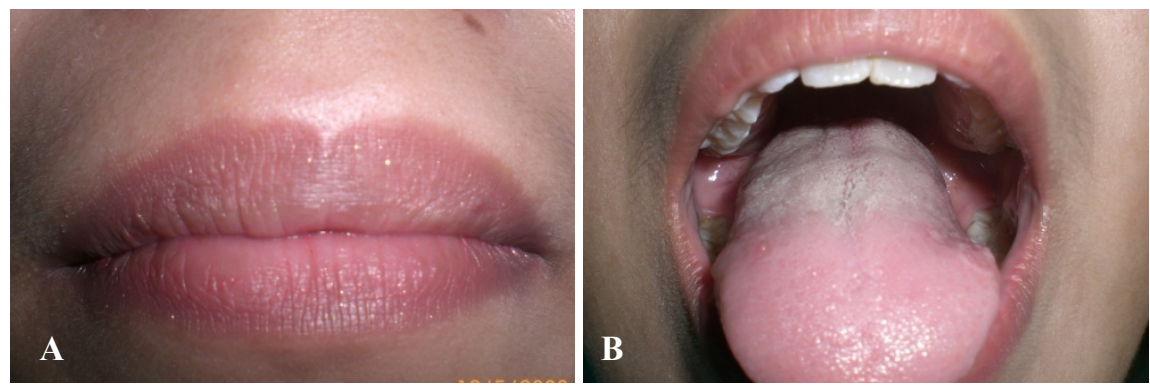

Gambar 3 Kontrol II; A lesi di atas bibir sembuh tanpa bekas, B lesi di lidah telah sembuh

Lima hari kemudian, pada kontrol pertama (gambar 2), dari anamnesis pasien diketahui bahwa nyeri telan telah hilang, sariawan di lidah sembuh demikian juga sariawan di daerah rugae palatina. Nyeri telan dan sariawan hilang setelah 3 hari sejak kunjungan pertama. Lesi di atas bibir pecah dan sembuh setelah hari ke-4 kunjungan pertama. Pasien masih merasa kurang nyaman pada kedua gigi molar paling belakang sebelah kiri dankanan rahang bawah.

Pemeriksaan ekstraoral menunjukkan krusta dan lesi vesikula lima hari yang lalu menjadi makula dengan diameter sekitar $3 \mathrm{~mm}$,dan pada pemeriksaan intraoral nampak peradangan pada molar ketiga kiri dan kanan rahang bawah.

Terapi selanjutnya pasien diberi acyclovir tablet $200 \mathrm{mg}, 5 \mathrm{x} 1$ untuk 2 hari, serta ekstrak aloe vera kumur dengan pemakaian $3 \times 1$ untuk 3 hari, dan diinstruksikan untuk melanjutkan pemakaian Echinacea $250 \mathrm{mg}$ tablet $1 \mathrm{x} 1$ dan multivitamin yang mengandung vitamin $\mathrm{E}$, vitamin $\mathrm{C}$, asam folat,vitamin $\mathrm{B} 1$, vitamin $\mathrm{B} 2$, niasin, vitamin $\mathrm{B} 6$, vitamin $\mathrm{B} 12$, asam pantotenant,dan $\mathrm{Zn}$, tablet $1 \mathrm{x} 1$ masing-masing untuk 1 minggu.

Sekitar enam minggu kemudian pasien datang kembali untuk memeriksakan nyeri pada daerah gigi molar rahang bawah kiri dan kanan paling belakang. Dari anamnesis diketahui tidak ada keluhan di lidah, di atas bibir dan lesi lain di rongga mulut. Pasien sudah sembuh dari infeksi herpes simpleks oral rekuren tiga hari sejak kontrol pertama. Akan tetapi pasien datang dengan keluhan tidak nyaman di kiri kanan gigi paling belakang rahangbawah (gambar 3).
Dari pemeriksaan ekstraoral tidak ada kelainan. Sementara pada pemeriksaan intraoral, didapati peradangan pada molar ketiga kiri dan kanan rahang bawah.

Untuk masalah tersebut, pasien dirujuk ke Bagian Bedah Mulut untuk melakukan perawatan pada gingiva molar kiri dan kanan rahang bawah.

\section{PEMBAHASAN}

VHS adalah virus DNA yang dibagi menjadi VHS-1 dan VHS-2. VHS-1 paling sering menyebar melalui mukosa rongga mulut. Saat berada pada permukaan epitelium, virion akan masuk melalui mekanisme fusi yang ada dalam selubungnya. VHS kemudian secaraproduktifmengalami replikasi pada daerah infeksidanmenyebar ke sel.Saat replikasi ini, beberapa virion akan terlepas dari sel yang terinfeksi dan mengikat pada terminal saraf sensoris yang terletak pada mukosa epitelium.VHS kemudian akan terbawa melalui fast axonal transport ke sel tubuh, atau soma neuron yang kemudian akan masuk ke dalam nukleus. Dalam nukleus ini, virus akan melakukan switching off lytic gene transcription sehingga memasuki masa laten.Lokasi utama VHS1 laten setelah infeksi mukosa oral adalah ganglion trigeminal. ${ }^{9}$

VHS-1 mengalami reaktivasi akibat stimulus berupa stres emosi, demam tinggi, paparan sinar ultraviolet,trauma jaringan oral atau jaringan saraf, ${ }^{3}$ imunosupresi,dan gangguan hormon. Patogenesis terjadinyareaktivasi inibelum diketahui pasti namun diperkirakan oleh karena terjadinya stimulus pada 
nukleus sensoris tempat dorman virus yang terjadi baik melalui stimulus sentral maupun perifer. ${ }^{9}$

Pada kasus ini,diagnosisklinisditegakkan sebagai infeksi herpes simpleks oral rekuren berdasarkan pada anamnesis yang menjelaskan adanya riwayat pernah terkena herpes dan berdasarkan gejala prodromal demam, seperti flu sebelum timbulnya sariawan, rasa menebal pada bibir atas, adanya pemicu berupa kelelahan fisik, serta berdasarkan gambaranklinis yang khas,yaitu adanya lesi vesikula $2 \mathrm{~mm}$ di atas bibir yang disebabkan oleh terjadinya replikasilokal fusi sel ke sel. ${ }^{9}$ Selain itu,juga ditandai dengan adanya krusta kering merah di atas bibir dan adanya lesi-lesi intraoral khususnya pada daerah nonkeratinisasi, yaitu rugae palatina.

Lynch membagi infeksi herpes simpleks oral rekuren menurut manifestasinya, yaitu lesi yang dijumpai pada daerah perioral yang disebut herpes labialis atau recurrent herpes labialis (RHL) dan lesi yangdijumpai diintraoral yang disebut recurrent intraoral herpes simplex infection (RIH). ${ }^{2}$

Secara klinis,lesi intraoral didiagnosis banding dengan stomatitis aftosa rekuren.Diagnosis ini tidak tepat oleh karena pasien baru mengalami untuk pertama kalinya, juga tidak ada riwayat stomatitis kambuhan sebelumnya.Sedang adanya lesi perioral, dengan bentuk vesikula dan krusta merah kecoklatan dapat memperkuat diagnosis sebagai infeksi herpes rekuren.Pada kasus ini tidak dilakukan pemeriksaan laboratorium, dan karena adanya gambaran vesikula di atas bibir serta adanya gejala prodromal demam yang terjadi sebelum timbulnya lesi. Gambaran ini khas,sehingga diagnosis herpes simpleks oral rekuren didiagnosis secara klinis. Sedang gambaran ulser di daerah rugae palatina yang merupakan daerah non keratinisasi,khas untuk lesi infeksi herpes simpleks intraoral.

Jika tidak dijumpai tanda khas lainnya, dapat dilakukan pemeriksaan usapan sitologi yang diambil dari dasar lesi yang baru saja pecah untuk membedakannya dengan lesi SAR. Pemeriksaan ini akan menunjukkan adanya ballooning degeneration serta multinucleated giant cell pada herpes labialis sedang pada SAR tidak. Usapan sitologi ini juga dapat diuji dengan menggunakan antigen VHS. Selain itu, juga dapat dilakukan kultur untuk membedakannya denganlesi virus lainnya,khususnya infeksi varicella zoster. ${ }^{2}$

Pasien kemudian diterapi dengan acyclovir 200 mg 5x1 selama 3 hari oleh karena infeksi ini tidak hanya merupakan lesi tunggal di atas bibir namun juga mengenai intraoral.Hal ini sesuai dengan artikel yang mengindikasikan dosis acyclovir sebanyak 200 mg 5x1 secara sistemik. ${ }^{6,7}$ Meski beberapa pustaka mengatakan bahwa pemberian antivirus acyclic analog nucleoside yang salah satunya adalah acyclovir, tidak lagi efektif untuk terapi antivirus setelah 72 jam, ${ }^{2}$ namun diharapkan pemberian antivirus ini dapat mengurangi frekuensi terjadinya rekurensi, ${ }^{5}$ dan terapi ini dapat mengurangi masa kesembuhan lesi 2 hari lebih cepat. ${ }^{2}$ Selain itu, aktivitas antivirus berupa inhibisi replikasi virus yang dilangsungkan dengan mengganti molekulDNA virus dan memutuskan rantainya,serta toksisitasnya yang rendah dengan efek yang terbatas untuk sel yang tidak terinfeksi karena adanya afinitas kinase thymidine yang spesifik untuk virus menjadikan antivirus ini pilihan unik untuk intervensi herpes simpleks oral rekuren. ${ }^{6}$ Kaplowitz dkk melaporkan hasil penelitiannya bahwa acyclovir merupakan profilaksis yang baik untuk herpes genital yang tidak terjadi rekurensi dalam satu tahun pertama. ${ }^{6}$ Sedang Spruance dkk,serta Rooney dkk melaporkan bahwa dosis acyclovir $400 \mathrm{mg} 2 \times 1$ efektif untuk menekan rekurensi herpes labialis. ${ }^{6,8}$

Pemberian obat kumur yang mengandung ekstrak aloe veradan sodium hyaluronate mempunyai tujuan simtomatis untukmengurangi rasa terbakar/cold sore yang dialami penderita.Sedang pemberian Echinacea $250 \mathrm{mg}$ dan multivitamin sebagai imunomodulator untuk mendukung perbaikan imunitas pasien sehingga diharapkan periode penyembuhan menjadi lebih cepat dan frekuensi rekurensi berkurang.

Pada kunjungan kedua, yaitu hari kelima sejak kunjungan pertama, keluhan pasien tinggal sedikit rasa tidak nyaman di bagian gigi paling belakang kiri dan kanan.Pada pemeriksaan ekstraoral,vesikula dan krusta 5 hari yang lalu menjadi makula dengan diameter $3 \mathrm{~mm}$. Secara umum,lesi ini muncul segera setelah adanya gejala prodromal, diikuti dengan munculnya lesi vesikula biasanya pada bibir atau di atas bibir selama 4-6 hari, yang kemudian akan pecah dan akan sembuh dalam masa 10 hari. ${ }^{5}$ Rasa tidak nyaman pada gigi paling belakang kiri dan kanan rahang bawah diduga adanya perikoronitis pada gigi molar rahang bawah kiri dan kanan. Semua terapi pada kunjungan pertama diteruskan.

Pada kunjungan ketiga, atau hari ke-64 sejak kunjungan pertama, bekas lesi di atas bibir telah sembuh seminggu setelah kunjungan kedua, sedang rencana perawatan untuk keluhan perikoronitis pasien dirujuk ke Bagian Bedah Mulut.

Disimpulkan bahwa kasus infeksi herpes simpleks oral rekuren. Terapi kausatif dengan pemberian acyclovir menunjukkan respon yang sangat baik, demikian jugadengan terapi suportif imunomodulator yang mendukung perbaikan sistem imun sehingga frekuensi rekurensi dapat dikurangi. 


\section{DAFTAR PUSTAKA}

1. Field A, Longman L. Mucocutaneous disease and connective tissue disorders. In: Field A, Longman L, Tyldesley RW. Tyldesley's oral medicine. $5^{\text {th }}$ Ed. London: Oxford University Press; 2003. p. 40.

2. Lynch A.M, Brightman JV, Greenberg SM. Burket: Ilmu penyakit mulut. $8^{\text {th }}$ Ed. Jakarta: Bina Rupa Aksara; 2003. p.67.

3. Raborn W, Grace GAM, McGAw WT. Herpes labialis in skiers. Oral Surg Oral Med Oral Pathol Oral Radiol Endod $1997 ; 84 ; 641-5$.

4. Boivin G, Goyette N, Sergerie Y, Keays S, Booth T. Longitudinal evaluation of herpes simplex virus DNA load during episodes of herpes labialis. J Clin Virol 2006; 37: 248-51.

5. Silverman S, Eversole RL, Truelove LE. Esssential of oral medicine. London: BC Decker Inc.; 2001.p.117-27.

6. Rabon WG, Martel YA, Grace AGM, McGaw WT. Oral acyclovir in prevention of herpes labialis. Oral Surg Oral Med Oral Pathol Oral Radiol Endod 1998; 85: 55-9.

7. Laskaris G. Treatment of oral diseases. $3^{\text {rd }}$ Ed. Stutgart: Thieme; 2003. p.66-7.

8. Woo SB, Challacombe SJ. Management of recurrent oral herpes simpex infection. Oral Surg Oral Med Oral Pathol Oral Radiol Endod 2007; 103: s12e1-s12e18. 